\title{
COMPARISON OF PERFORMANCE OF LATERAL LOAD RESISTING SYSTEMS IN MULTI STOREY FLAT SLAB BUILDING
}

\author{
Muralidhar G.B ${ }^{1}$, Swathi Rani K.S ${ }^{2}$ \\ ${ }^{1}$ Lecturer, Civil Engineering Department, University of Gondar, Ethiopia \\ ${ }^{2}$ Assistant Professor, Civil Engineering Department, East West Institute of Technology, Karnataka, India
}

\begin{abstract}
This paper introduces the comparison between lateral load resisting systems in multi storey building. Multi storey building composed of very special class of structure and therefore require special treatment. Hence to overcome the effects of seismic forces, Flat slab system in which slab rests on drop or capital which is connected to column is induced with different load resisting systems. The combined systems which is used to withstand seismic forces in this study are 1. Flat slab without lateral load resisting system, 2. Flat slab with shear wall, 3. Flat slab with infill wall, 4. Flat slab with bracings, 5. Flat slab with shear wall and bracings. ETABS software version is used to accomplish dynamic analysis and also building is investigated for nonlinear static analysis in order to identify seismic demands. From the obtained results conclusions are drawn.
\end{abstract}

Keywords: Capital, Bracings, Dynamic, and Treatment etc...

\section{INTRODUCTION}

The desolating social and economic impacts of recent earthquakes in urban areas have resulted towards the awareness of the potential seismic hazard and the answering susceptibility of the environment. As being one of the particular reinforced concrete structural forms, Flat slab systems require further attention. These flat slab building structures are significantly more flexible than traditional beam slab under earthquake excitation. The flat slab system in high earthquake region shows significant risk, brittle punching failure arises from the transfer of shearing force and unbalanced moment between slab and column which leads to progressive collapse of structure. To prevent this failure from earthquake forces lateral load resisting systems play a important role. Also, the undesirable behavior has originated from the insufficient lateral resistance due to the absence of lateral load resisting systems such as shear wall, infilled Frame, braced frame, Outrigger braced, Suspended, Space structures, and Core system. etc. But our study is restricted to first three types respectively.

\subsection{Overview of Lateral Load Resisting System}

Many structural systems to provide the different architectural needs are available in steel as well as concrete. For well-formed design of structure, an understanding of the behavior of the structural system is necessary. The following section gives an overview of the behavior of various lateral load resisting systems.

Infill Wall: Reinforced concrete frames with masonry infills are a popular form of construction of multi- storey building around the world. Usually, the frame is filled with bricks as non- structural wall for partition of rooms. The buildings are generally designed as frame structure without regard to structural action of masonry infill walls. In the present practice of structural design in India masonry infill panels are treated as non- structural element and their strength and stiffness contributions are neglected.

Shear wall: Shear wall is a slender vertical cantilever, resisting the lateral load with or without frames. It will resist the lateral load in flexure with very little shear deformation. Depending on the size of openings the behavior of shear wall varies. To control ill-effects of twist in structures, Shear walls are to be placed symmetrically in plan also along one or both directions in plan and more effective when placed along exterior perimeter of the structure.

Braced Frame: To resist earthquake load in multi storied building steel braced structural frame is extensively used. Concentrically Braced Frames (CBFs) are a class of structures resisting lateral loads through a vertical concentric truss system, the axes of the members aligning concentrically at the joints. CBFs tend to be efficient in resisting lateral forces because they can provide high strength and stiffness. CBFs are a common structural steel or composite system in areas of any seismicity. The steel braced systems are used to abate drift demand.

\section{MODELLING AND ANALYSIS OF THE BUILDING}

In the present study, analysis is done by ETABS software. For the analysis, material properties like Grade of concrete, size of structural elements, various loads are given in below in Table-1. Plan and elevation of all the analytical model with a different lateral load resisting system are shown in Fig 1 to Fig 6 
Table -1: Modelling Properties of the Multi storied building

\begin{tabular}{|c|c|}
\hline Grade Of Concrete & M-25,M-35,M-40 \\
\hline Beam Size & 300x600mm, M25 \\
\hline Column Size & $600 \times 600 \mathrm{~mm}, \mathrm{M} 35$ \\
& $600 \times 600 \mathrm{~mm}, \mathrm{M} 40$ \\
\hline Drop thickness & $200 \mathrm{~mm}$ \\
\hline Slab thickness & $175 \mathrm{~mm}$ \\
\hline Imposed Load : & $3.0 \mathrm{KN} / \mathrm{m} 2$ \\
\hline Floor Finish \& Partitions & $2.0 \mathrm{KN} / \mathrm{m} 2$ \\
\hline Specific Weight of RCC & $25 \mathrm{KN} / \mathrm{m} 3$ \\
\hline Type of Soil & $\mathrm{III}$ \\
\hline Response Spectra & As per IS 1893 (Part- 1) 2002 \\
\hline Damping & $5 \%$ \\
\hline Importance Factor & 1.5 \\
\hline Response reduction Factor & 5.0 \\
\hline Seismic Zone & $\mathrm{V}$ \\
\hline Number of storeys & Basement + Ground floor+8 \\
\hline
\end{tabular}

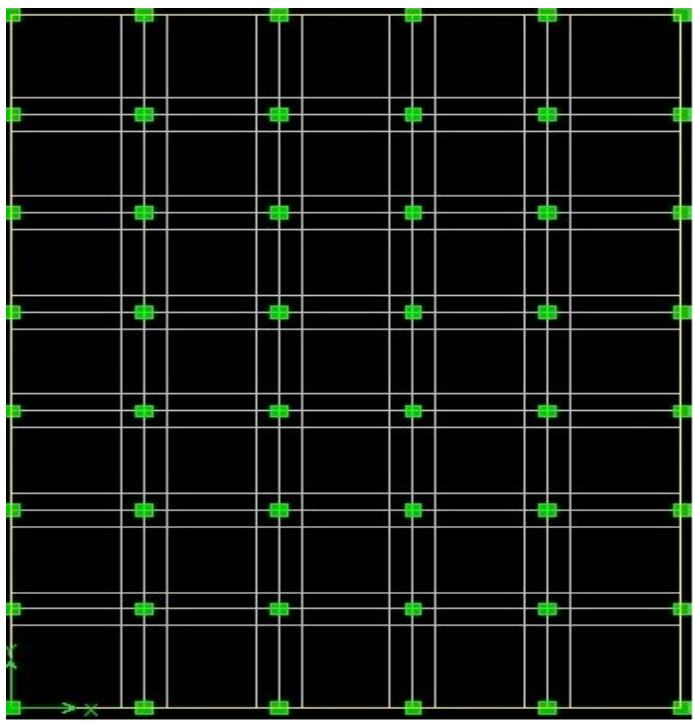

Fig -1: Plan of the building model

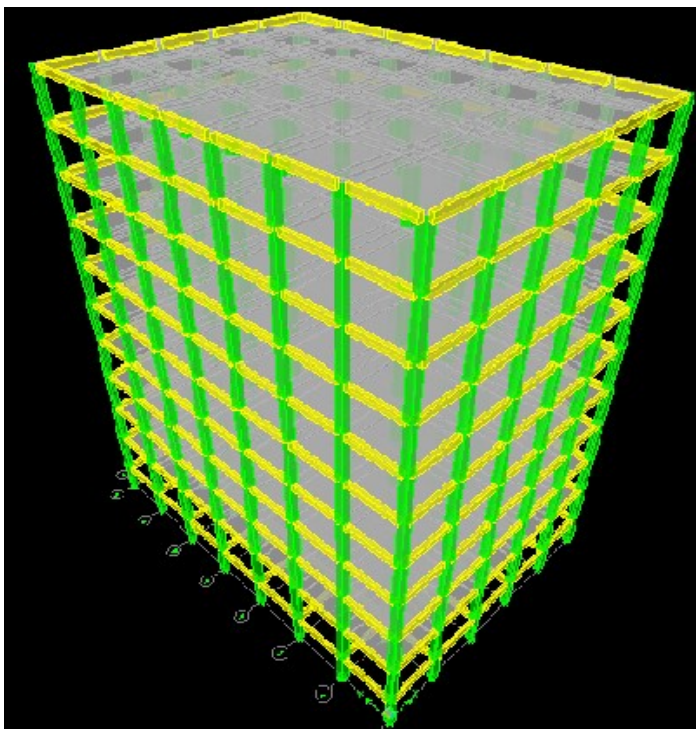

Fig -2: Bare Frame structure (Model-I)

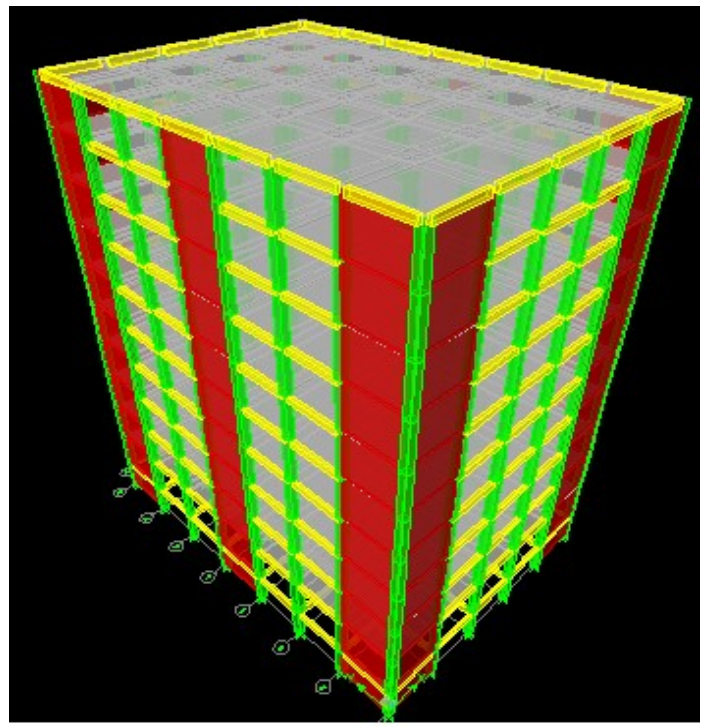

Fig -3: Structure with shear wall (Model-II)

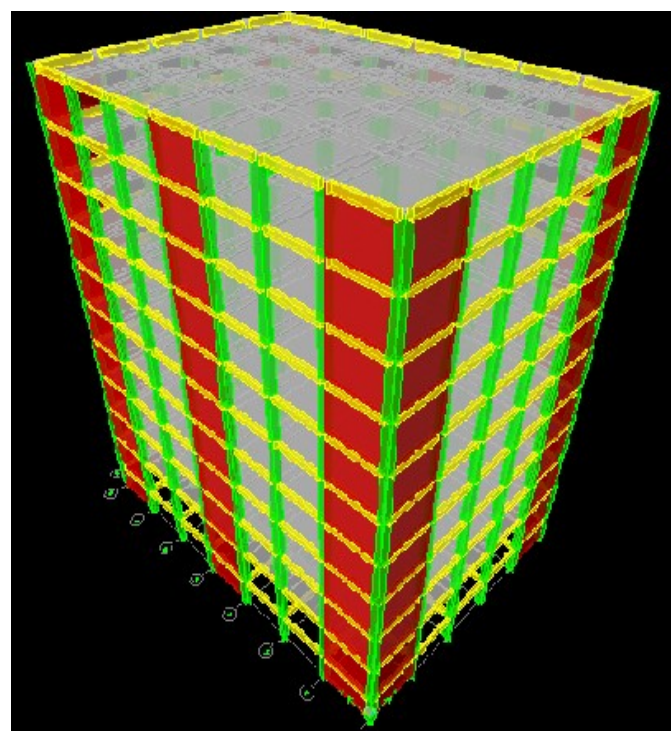

Fig -4: Structure with infill wall (Model-III) 


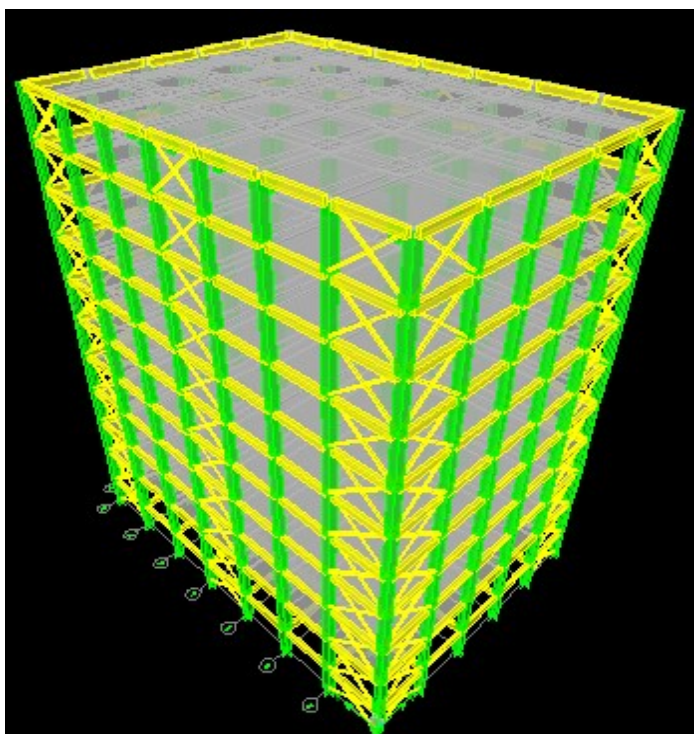

Fig -5: Structure with Bracings (Model-IV)

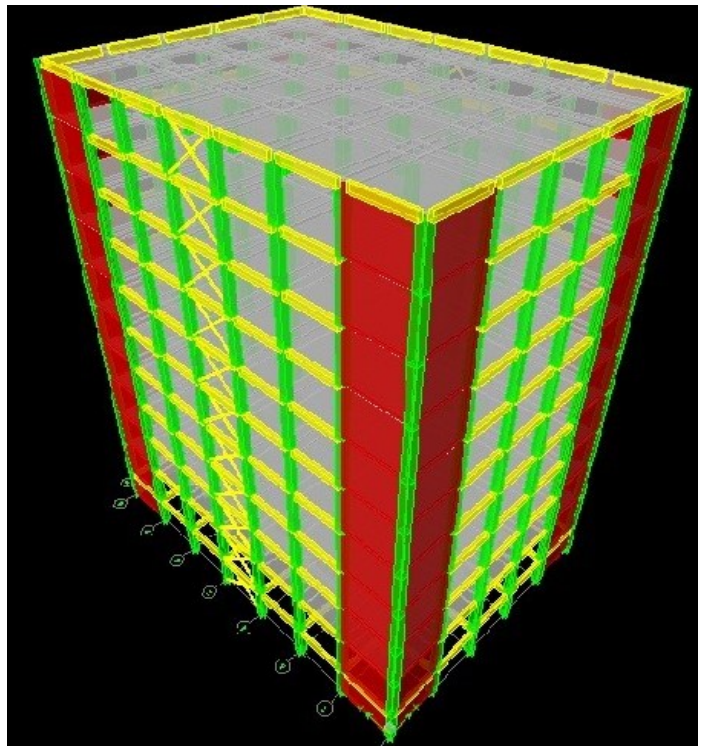

Fig -6: Structure with Shear wall \& Bracings (Model-V)

\section{RESULTS AND DISCUSSIONS}

Table -2: Dynamic Properties of the Multi storied building

\begin{tabular}{|c|c|c|c|c|c|c|c|c|c|c|c|c|c|c|}
\hline \multirow{2}{*}{$\frac{\dot{0}}{\frac{\dot{z}}{8}}$} & \multirow{2}{*}{ 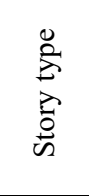 } & \multicolumn{4}{|c|}{ Base Shear in KN } & \multirow{2}{*}{\multicolumn{2}{|c|}{ Scale up Factor }} & \multirow{2}{*}{\multicolumn{3}{|c|}{ Time period in seconds }} & \multirow{2}{*}{\multicolumn{2}{|c|}{$\begin{array}{c}\text { Max.story } \\
\text { displacement of } \\
\text { 10th floor in mm }\end{array}$}} & \multirow{2}{*}{\multicolumn{2}{|c|}{$\begin{array}{c}\text { Max.story drift } \\
\text { of Ground } \\
\text { floor in } \mathrm{mm}\end{array}$}} \\
\hline & & \multicolumn{2}{|c|}{$\begin{array}{c}\text { Equivalent Static } \\
\text { Method }\end{array}$} & \multicolumn{2}{|c|}{$\begin{array}{c}\text { Response } \\
\text { Spectrum Method }\end{array}$} & & & & & & & & & \\
\hline 1 & upto8 & 6543.55 & 6543.55 & 3285.13 & 3491.91 & 2.93 & 2.75 & 2.174 & 2.029 & 1.783 & 198.069 & 171.074 & 4.551 & 4.137 \\
\hline 2 & upto8 & 7148.75 & 7148.75 & 6143.07 & 6753.17 & 1.71 & 1.55 & 1.147 & 1.007 & 0.663 & 67.277 & 52.054 & 0.8886 & 0.672 \\
\hline 5 & upto8 & 7046.46 & 7046.46 & 6067.13 & 6554.21 & 1.70 & 1.58 & 1.18 & 1.071 & 0.705 & 71.24 & 58.277 & 0.879 & 0.747 \\
\hline
\end{tabular}

\section{*NOTE: Upto8 means Basement + Ground floor +8}

Table -3: Performance point and Hinge status in longitudinal and transverse direction for all flat slab building models

\begin{tabular}{|c|c|c|c|c|c|c|c|c|c|c|c|c|}
\hline \multirow[b]{2}{*}{ Storey } & \multirow[b]{2}{*}{ Models } & \multirow[b]{2}{*}{$\begin{array}{c}\text { Displace } \\
\text { ment in mm }\end{array}$} & \multirow[b]{2}{*}{$\begin{array}{c}\text { Base Force in } \\
\mathrm{kN}\end{array}$} & \multicolumn{8}{|c|}{ Performance levels } & \multirow[b]{2}{*}{ Total Hinges } \\
\hline & & & & A-B & $\mathrm{B}-\mathrm{IO}$ & $\begin{array}{l}\text { IO- } \\
\text { LS }\end{array}$ & $\begin{array}{l}\text { LS- } \\
\text { CP }\end{array}$ & $\begin{array}{c}\text { CP- } \\
\mathrm{C}\end{array}$ & $\begin{array}{l}\text { C- } \\
\text { D }\end{array}$ & $\begin{array}{l}\text { D- } \\
\text { E }\end{array}$ & $>\mathrm{E}$ & \\
\hline \multirow{2}{*}{$\mathrm{B}+\mathrm{G}+8$} & $\begin{array}{l}\text { Model - I-X- } \\
\text { direction }\end{array}$ & 190.942 & 6543.552 & 2076 & 222 & 46 & 0 & 0 & 0 & 0 & 0 & 2344 \\
\hline & $\begin{array}{l}\text { Model - I-Y- } \\
\text { direction }\end{array}$ & 171.549 & 6543.552 & 2006 & 300 & 38 & 0 & 0 & 0 & 0 & 0 & 2344 \\
\hline \multirow{2}{*}{$\mathrm{B}+\mathrm{G}+8$} & $\begin{array}{l}\text { Model-II-X- } \\
\text { direction }\end{array}$ & 53.5298 & 7148.746 & 2248 & 96 & 0 & 0 & 0 & 0 & 0 & 0 & 2344 \\
\hline & $\begin{array}{l}\text { Model -II-Y- } \\
\text { direction }\end{array}$ & 40.104 & 7148.746 & 2254 & 90 & 0 & 0 & 0 & 0 & 0 & 0 & 2344 \\
\hline \multirow{2}{*}{$\mathrm{B}+\mathrm{G}+8$} & $\begin{array}{l}\text { Model - III-X- } \\
\text { direction }\end{array}$ & 59.601 & 7027.708 & 2242 & 102 & 0 & 0 & 0 & 0 & 0 & 0 & 2344 \\
\hline & $\begin{array}{l}\text { Model - III-Y- } \\
\text { direction }\end{array}$ & 44.025 & 7027.708 & 2244 & 100 & 0 & 0 & 0 & 0 & 0 & 0 & 2344 \\
\hline \multirow{2}{*}{$\mathrm{B}+\mathrm{G}+8$} & $\begin{array}{l}\text { Model - IV-X- } \\
\text { direction }\end{array}$ & 81.682 & 6637.299 & 2220 & 124 & 0 & 0 & 0 & 0 & 0 & 0 & 2344 \\
\hline & $\begin{array}{l}\text { Model - IV-Y- } \\
\text { direction }\end{array}$ & 57.396 & 6637.299 & 2210 & 134 & 0 & 0 & 0 & 0 & 0 & 0 & 2344 \\
\hline \multirow{2}{*}{$\mathrm{B}+\mathrm{G}+8$} & $\begin{array}{l}\text { Model - V-X- } \\
\text { direction }\end{array}$ & 53.347 & 7046.457 & 2248 & 96 & 0 & 0 & 0 & 0 & 0 & 0 & 2344 \\
\hline & $\begin{array}{l}\text { Model - V-Y- } \\
\text { direction }\end{array}$ & 42.421 & 7046.457 & 2254 & 90 & 167 & 0 & 0 & 0 & 0 & 0 & 2344 \\
\hline
\end{tabular}




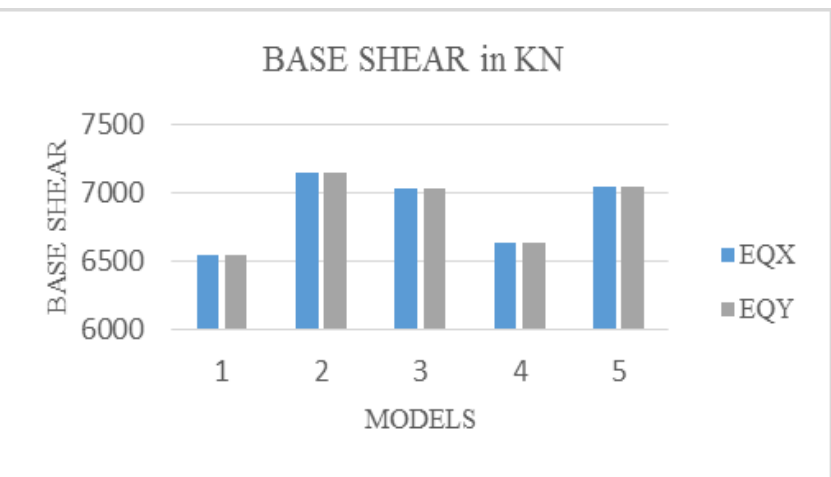

Chart -1: Shows the performance of model v/s base shear for EQ method

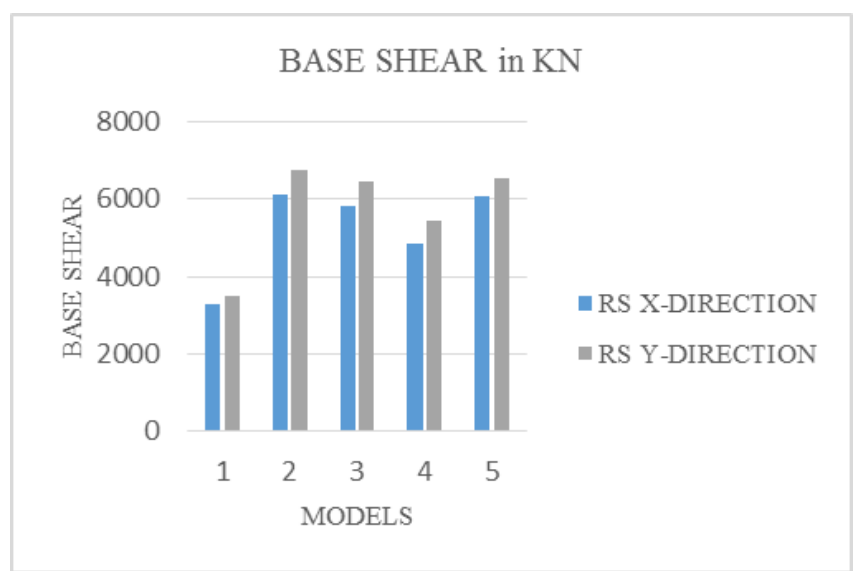

Chart -2: Shows the performance of model v/s base shear for RS method

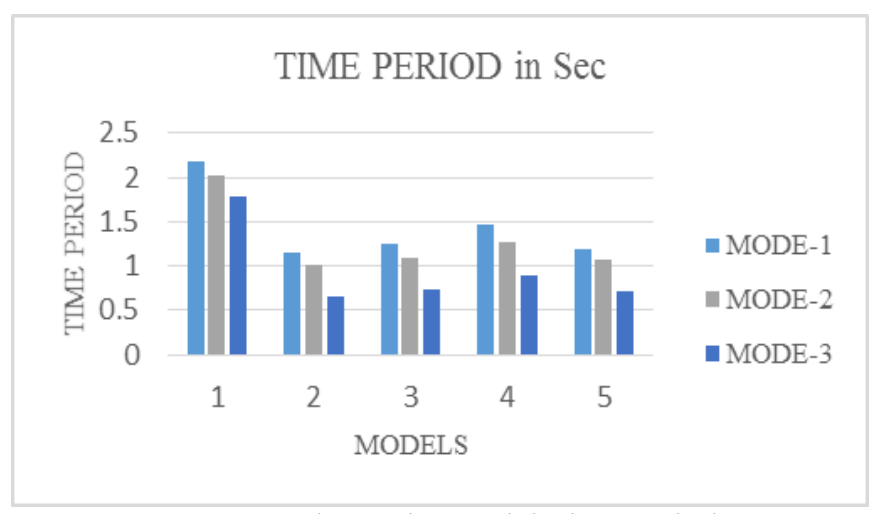

Chart -3: Shows the Modal Time period

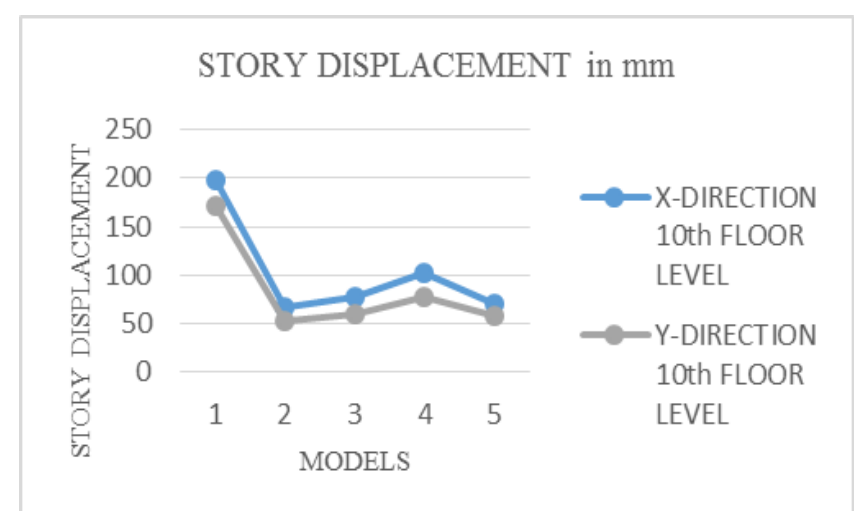

Chart -4: Shows the performance of Story Displacement in $\mathrm{X} \& \mathrm{Y}$ direction at $10^{\text {th }}$ level

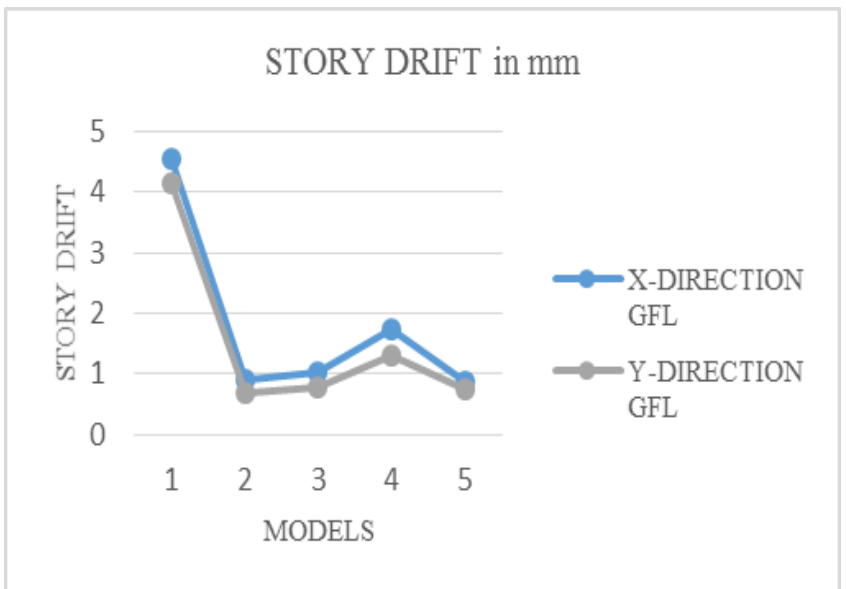

Chart -5: Shows the performance of Story Drift in X \& Y direction at GF level

\section{CONCLUSIONS}

This study concentrates on accomplishment of RC flat slab multistory building comprehending of various lateral load resisting systems like shear wall, infill wall and bracings. These models are analyzed for seismic zone V of IS 18932002 Part-I. Comparisons are done with various dynamic properties we can assess the seismic vulnerability of the building. The apprehension of plastic hinges are examined by performing nonlinear static analysis. The adoption of push over analysis focus on the effect of correct lateral load pattern, this will maintain the prejudicial persuasion of seismic performance of flat slab building. From the obtained above results we can conclude:

1. The performance level of all the Flat slab building models in longitudinal and transverse direction are found within B-IO (between operational and immediate occupancy) except in model 1. Hence incorporation of lateral load resisting system will perform well.

2. From obtained results, due to non-linear analysis the total number of plastic hinges of all the models are same. But, performance base shear found to be more in Flat slab building with shear wall with decrease in performance displacement.

3. Time period in Flat slab building with shear wall (Model 2) is comparatively less than other models. Even, building with shear wall and bracings (Model 5) shows less time period. But, stiffness and strength of Model 2 is more than Model 5.

4. There is an increase in base shear for Flat slab building with shear wall (Model 2) due to more mass and stiffness compared to other models.

5. Use of Flat slab with drop increases the drift value. But providing lateral load resisting system limits the drift in the structure. Building with shear wall (Model 2) experience less drift compared to other models.

6. Incorporating lateral load resisting system in Flat slab building will rapidly reduce the lateral displacement. So, as observed in all the models adoption of shear wall shows less displacement thereby assures the safety to the structure. 


\section{REFERENCES}

[1].Andreas J Kappos , Georgios Panagopoulos (2004), "Performance-based seismic design of 3D R/C buildings using inelastic static and dynamic analysis procedures", ISET journal of earthquake technology, paper no. 444, vol. 41, no. 1, pp. 141-158.

[2].Apostolska1 R.P and Necevska-Cvetanovska G. S, "Seismic performance of flat-slab building structural systems" The 14th World Conference on Earthquake Engineering October 12-17, 2008, Beijing, China

[3].Ashraf Habibullag, S.E. and Stephen Pyle S.E. “ Practical Three Dimensional Nonlinear Static Pushover Analysis" published in Structural Magazine, Winter, 1998.

[4].FEMA 308 (1998), "Evaluation of earthquake damaged concrete and masonry buildings", Federal Emergency Management Agency", Washington D.C.

[5].I.S. 1893, "Criteria for Earthquake Resistant Design of Structures (part 1) General Provisions and Buildings (Fifth Revision)", Bureau of Indian Standards, 2002.

[6].Mr. Muralidhar G.B and Mrs. Swathi Rani K.S,"Comparison of Seismic Susceptibility Assessment of Low to Medium Rise RC Buildings by Considering the Effect of Shear wall", International Journal of Science, Engineering and Technology, Volume 3 Issue 6, 2015

[7].Mr. Muralidhar G.B and Mrs. Swathi Rani K.S," Study of Seismic Performance of RC Building with Flat Plate Influenced by Concrete Wall", International Research Journal of Engineering and Technology, Vol.3, Issue No. 1:357-361, 2016.

[8].Sabri Attajkani, Abdellatif Khamlichi," Modelling the Effect of Infill Walls on Seismic Performance of Reinforced Concrete Buildings", International Journal of Engineering Research and Applications, Vol. 3, Issue 1, January-February 2013, pp.1178-1183

[9]. Sachin Dhiman, Mohammed Nauman," Behaviour of Multistory Steel Structure with Different Types of Bracing Systems (A Software Approach)", International Refereed Journal of Engineering and Science, Volume 4, Issue 1 (January 2015), PP.70-82 